\title{
Cumulative Cost Spent on Construction Projects of Different Sectors
}

\author{
Jarosław Konior, Mariusz Szóstak* \\ Department of Building Engineering, Faculty of Civil Engineering, Wroclaw University of Science and Technology, Poland
}

Received March 11, 2021; Revised April 16, 2021; Accepted May 23, 2021

\section{Cite This Paper in the following Citation Styles}

(a): [1] Jarostaw Konior, Mariusz Szóstak, "Cumulative Cost Spent on Construction Projects of Different Sectors," Civil Engineering and Architecture, Vol. 9, No. 4, pp. 999 - 1011, 2021. DOI: 10.13189/cea.2021.090404.

(b): Jarosław Konior, Mariusz Szóstak (2021). Cumulative Cost Spent on Construction Projects of Different Sectors. Civil Engineering and Architecture, 9(4), 999 - 1011. DOI: 10.13189/cea.2021.090404.

Copyright $\odot 2021$ by authors, all rights reserved. Authors agree that this article remains permanently open access under the terms of the Creative Commons Attribution License 4.0 International License

\begin{abstract}
The purpose of the paper is to analyse and evaluate the course of various construction projects and to compare the planned, incurred and actual costs. Moreover, the authors aim to indicate the basic causes of cost deviations from the earned values, i.e., those that were really performed on a construction site. The data on the development of the original research methodology come from the authors' own experience and professional work involving the providing of Bank Investment Supervision services in the years 2006 - 2019 on behalf of banks granting investment loans for non-public contracts. The authors of the article collected and processed cost data by conducting monthly direct technical and financial inspections at construction sites of implemented investments. The measurement of the cost and budget of investment tasks was documented in 536 technical and financial reports. A database was built in the form of tables that were prepared for the purpose of value and cumulative analyses of the cost and time of 40 construction projects measured in a monthly cycle from 8 different investment sectors. On their basis, charts of planned / estimated, invoiced / incurred, and actual / earned values of the cumulative costs of the examined construction projects were prepared. The elaborated levels of the amounts of construction that works to be executed were determined using the S-curve. The selected, planned, incurred and actual cost graphs in homogeneous groups, and also earned cost graphs in a diverse group were presented. The conducted studies, which are briefly presented in the article, relate to various construction projects concerning 8 typological research samples. Analyses were carried out in accordance with the methodology of the Earned Value
\end{abstract}

Method (EVM), which enables the actual achieved budgets of various investment tasks to be assessed. Analogies in the arrangement of cumulative cash flow curves were observed within the same groups of buildings, and also between them. Such information is fundamental in terms of controlling and predicting of cost and schedule performances within homogeneous construction sectors. Planning diverse investments budget and timeframe the executives may foresee in measurable way the most probable spend of actual and earned values of managed projects. They can estimate the range of cost and schedule overrun at the construction project completion and set up mitigation actions to minimise the risks of such overrunning.

Keywords Construction Project, Cumulative Cost, S-Curve, Earned Value Method, Bank Investment Supervision

\section{Introduction}

\subsection{Cost in the Earned Value Method (EVM) Approach}

The execution of a construction object within the assumed budget and schedule, while at the same time ensuring the quality standard, is a key factor that determines the success of a construction project [1]. This requires the appropriate planning and effective monitoring of each parameter at the successive stages of an 
investment task [2]. The fundamental issue is the analysis of the time and costs of implementing a project, especially during its construction phase, when $75 \%-80 \%$ of the estimated expenditure on construction works is utilized [3]. Investment tasks are constantly exposed to many random factors that violate their efficient course [4-6]. Controlling the course of works, and regular examination of any deviations in time and costs during the implementation seems to be an absolute necessity $[7,8]$.

Engineers usually express work progress by referring to it as a schedule or plan of costs. As changes or divergences in activities are a normal situation in real construction projects, integrated and complex methods of analysis are needed to describe the real state of a project [9]. The Earned Value Method (EVM) is recommended as a global standard for measuring project effectiveness [10], which consists of verifying an investment task by cyclically comparing the actual scope of works performed with their planned cost and time of completion $[11,12]$.

An effective tool for measuring the incurred financial expenditure on a task is the presentation of the planned financial flows on a time axis using a cumulative cost chart, the picture of which is the S-curve [13]. The EVM method - the graphic image of which are three S-curves is considered as an advanced technique for controlling projects and for providing the results of calculations in the form of quantitative and qualitative indicators. The basis of project control when using the EVM method is to compare the scope of works performed with their actual dates of completion, and the actual incurred costs with the schedule and budget that were planned in the project $[14,15]$. Traditional methods of controlling construction works are based on two separate scopes. The first compares the actual progress of works with their schedule, and the second includes the financial control of the project, i.e., the comparison of actual costs with the planned costs at the time of control. However, this approach does not take into account the relationship between the progress of works and their costs. In comparison with the traditional method of controlling progress when implementing a construction project, the EVM takes into account - in addition to the planned and actual costs - the so-called third parameter, i.e., the earned value, which corresponds to the planned value of the actual scope of work performed [16,17].

The purpose of the research is to analyse and evaluate the course of various construction projects, to compare the planned, incurred and actual performed schedule and cost, and to indicate the basic causes of cost deviations from earned values, i.e., those actually performed on a construction site.

The article presents an analysis and assessment of the planned, current and actual performed cost of various construction projects included in the research sample with over half a thousand measurements. The calculations were made in accordance with the methodology of the Earned
Value Method.

\subsection{Literature Review}

The appropriate planning and effective controlling and monitoring of the execution of construction projects are essential for the successful implementation of a project. The basic determinant of successful project management involves the achieving of the following objectives: guaranteeing quality, timeliness, and the implementation of the facility within the planned budget $[18,19]$. Budget planning at the stage of preparing an investment project, as well as monitoring and controlling cash flows in the project during its implementation, is of key importance for investors, project managers and contractors of construction works [20]. During the implementation of projects, cash flows are important for assessing the expenditure planning, order fulfilment, payments to subcontractors, and the demand for working capital [21].

For this purpose, various methods, techniques and tools are being developed in order to monitor the parameters of investment tasks and to forecast the final results [22-24]. The implementation of these objectives is supported by: striving to standardize processes, the efficient organization of an investment, and the establishment of the Work Breakdown Structure (WBS) [10,25,26]. WBS is the planning foundation that determines the material scope of a project. It covers grouped elements of the enterprise with regards to products, indirect effects, the entire product to be manufactured, and also the expenditure that is necessary for their production. Moreover, in order for the planning, scheduling and monitoring of project implementation to be effective, it is necessary to use the assistance of computer project management systems [27]. Regular assessment of the progress of works using IT tools enables the effectiveness of activities at a construction site to be reflected, while at the same time an analysis to be conducted [28,29].

The Earned Value Method involves a comprehensive group of methods that are used to control and monitor the progress of construction projects [30]. The method is based on controlling an investment task by cyclically comparing the actual scope of works performed with their planned time and cost of implementation in accordance with the planned schedule and project budget that were adopted at the beginning of the task [31]. The analysis and evaluation of an investment during its implementation is a complex and advanced technique. Project management using the Earned Value Method is a well-known multidimensional management system that integrates the costs, schedule and technical performance [32]. The method enables relatively uncomplicated indicators for cost and schedule deviations, as well as performance parameters, project cost forecasts, and schedule duration to be calculated [33].

All deviations are best monitored using the S-curve, 
which shows the cost flow during the project duration [34]. Curves of planned and actual cost, as well as the earned value can be compared in a graphical view [35]. A method of on-going improvement of the actual cost curve may be used in order to rationally assess the deadline or the actual costs of an investment. The actual cost curve is usually similar to the S-curve. It is possible to use third-degree polynomials for the on-going update of the above-mentioned curve. For the correct approximation of the S-curve, it is important to correctly define the inflection point of the curve. Unfortunately, when planning a construction investment, as well as when making changes to the budget during the implementation of works, this point is difficult, and sometimes even impossible, to determine [36].

The classic Earned Value Method is being expanded and constantly modified due to conducted research. A new parameter was introduced to the basic method - the Schedule Forecast Indicator (SFI). It aims to support decision-makers in the decision-making process in the case when changes occur in a project at various stages [37]. In the conducted research regarding the extension of the Earned Value Method, attempts were made to take into account the impact of unplanned time and cost deviations on the financial liquidity of a construction project. To this end, three groups of models were analysed: scenarios in which the planned budget was exceeded while the planned duration was maintained; scenarios in which the planned duration was exceeded while the planned costs were maintained, and scenarios in which the planned costs and the duration of the investment task were exceeded simultaneously [38].

Despite the widespread use and the ensuring of a relatively accurate assessment, the Earned Value Method is not without its flaws. There are some inaccuracies and problems with its practical application. An important problem involves a difficulty in the correct and unequivocal determination of the percentage of the advancement of work performed, especially tasks that have been started but are not completed at the time of inspection [39]. These irregularities may lead to misinterpretations of the obtained indicators, as well as to the drawing of incorrect conclusions regarding the effects of deviations that are based on them, including the estimated deadlines and project costs [40]. As highlighted by the conducted research, the forecasted cost and duration are very sensitive to the data used in the analysis. In order to obtain the most reliable and actual estimate of the costs and duration of an investment, analyses should be carried out according to the actual progress of the project.

The estimated actual costs and duration are not reliable in the first period of an investment, and they stabilize in the second period, in which, depending on the scenario adopted for further work, they estimate the actual values with high accuracy. In addition, all indicators are calculated in monetary units, including a deviation from the schedule, which makes the analysis and evaluation of results difficult. If the implementation of a project exceeds the assumed deadline, the method shows irregularities, i.e., it indicates that the project was implemented in accordance with the plan. These difficulties have influenced the development of formulas and methods for more reliable forecasting of the total cost and deadline of projects, e.g., by introducing hybrid methodology that is based on construction packages and the logical analysis of time [41], by introducing hybrid artificial intelligence [42], or by considering the impact of unplanned time and cost deviations on the financial liquidity of a construction project [38].

A thorough analysis of the publications cited in the authors' article comes to a conclusion that the previously proposed models of forecasted S-curves usually deviate from reality and are too complicated. Therefore, they are not practical when planning and managing construction projects, because the cumulative cost curves are unique. Each investment project has an individual character. Each construction project is located in a different place, and in a different geographical environment. In addition, it is designed and implemented by various teams of people with different professional qualifications and experience. Construction works are carried out using various technical, organizational and technological solutions. Each construction project is therefore a separate and unique investment task with its own specificity, difficulties, uncertainties and risks [43].

\section{Method and Research Sample}

The method of measuring the parameters of the Earned Value Method (EVM) is well represented and described in detail in the methodology of the engineering work of the Bank Investment Supervision (BIS), which is obliged to reliably measure the course of cost and time, their variability, and the level of implementation of various investment tasks $[44,45]$.

The data obtained for the development of the author's analyses, which are presented in the article, come from 15 years of research conducted by Jarosław Konior, and 4 years of analysis by Mariusz Szóstak, who provide Bank Investment Supervision services on behalf of banks granting investment loans for non-public orders. The results of 536 measurements concern 40 construction investments in Poland in 8 construction sectors [31] - Tab. 1. 
Table 1. Summary of the number of analysed construction projects and obtained reports

\begin{tabular}{|c|c|c|c|}
\hline Category & $\begin{array}{c}\text { Sector of BIS } \\
\text { projects }\end{array}$ & $\begin{array}{c}\text { Number of } \\
\text { projects }\end{array}$ & $\begin{array}{c}\text { Number of } \\
\text { reports }\end{array}$ \\
\hline A & $\begin{array}{c}\text { Residential } \\
\text { Buildings }\end{array}$ & 14 & 189 \\
\hline B & Office Buildings & 4 & 58 \\
\hline C & Hotel Buildings & 9 & 110 \\
\hline D & $\begin{array}{c}\text { Commercial and } \\
\text { Leisure Centres }\end{array}$ & 8 & 113 \\
\hline E & Logistic Centres & 3 & 12 \\
\hline F & Health Centres & 1 & 12 \\
\hline G & $\begin{array}{c}\text { Airport } \\
\text { Developments }\end{array}$ & 1 & 36 \\
\hline H & Production Plants & 1 & 6 \\
\hline A-H & Totals & 41 & 536 \\
\hline
\end{tabular}

The analysis of investments was carried out in accordance with the methodology of the Earned Value Method. The basic work and expenditure schedule developed by investors before the commencement of works, and information regarding the actual progress of implementation that was derived from monthly BIS reports, were examined. The reports were prepared by the inspectors of the Banking Investment Supervision, who participated in the investment process [46]. The data contained in the reports are based on a thorough analysis of settlements and invoices, and also on the direct technical and financial inspections carried out on construction sites for the purpose of measuring the actual amounts of construction works performed and the progress of the schedule at the time of the inspection. Reports were made in the same standardized way of collecting data on construction projects. The course of the S-curves was determined on the basis of increasing values of the amounts of works performed, which constituted the cumulative cost determined systematically by the same authors. Each value of the cost of works performed was subjected to repeated verifications and checking - in the first stage by the General Contractor and Subcontractors, then by Multi-Branch Supervision Inspectors, followed by the Banking Investment Supervision Team, and finally by the Financing Bank. Therefore, the analysed data is reliable, consistent and ordered.

For the purpose of the study, a collective data summary was prepared, and the basic parameters and indicators of the Earned Value Method were determined. Tables containing the following cumulative values were prepared for each construction project:

- the budgeted cost of work scheduled - BCWS, determined for each individual billing period and the type of works to be performed on the basis of the Investor's work and expenditure schedule;

- the budgeted cost of work performed - BCWP, determined for each individual billing period on the basis of BIN reports;

- the actual cost of work performed - determined for each individual billing period on the basis of BIN reports.

Table 2 presents an exemplary summary statement of the cumulative values for an exemplary investment.

Table 2. Summary of the analysed values for an exemplary investment

\begin{tabular}{|c|c|c|c|c|}
\hline \multirow{2}{*}{ No. } & \multirow{2}{*}{ Period } & $\begin{array}{c}\text { The budgeted cost of work } \\
\text { scheduled }\end{array}$ & $\begin{array}{c}\text { The budgeted cost of work } \\
\text { performed }\end{array}$ & $\begin{array}{c}\text { The actual cost of work } \\
\text { performed }\end{array}$ \\
\hline & & BCWS & BCWP & ACWP \\
\hline (1) & (2) & (3) & (4) & (5) \\
\hline 1 & Mar. 2017 & $1,025,000.00$ & $1,055,000.00$ & $1,055,000.00$ \\
\hline 2 & Apr. 2017 & $2,125,000.00$ & $2,305,000.00$ & $2,305,000.00$ \\
\hline 3 & May. 2017 & $3,255,000.00$ & $3,305,000.00$ & $3,305,000.00$ \\
\hline 4 & Jun. 2017 & $4,705,000.00$ & $4,153,000.00$ & $4,153,000.00$ \\
\hline 5 & Jul. 2017 & $5,855,000.00$ & $5,211,400.00$ & $5,211,400.00$ \\
\hline 6 & Aug. 2017 & $7,295,000.00$ & $6,329,000.00$ & $6,329,000.00$ \\
\hline 7 & Sep. 2017 & $8,938,000.00$ & $7,231,000.00$ & $7,231,000.00$ \\
\hline 8 & Oct. 2017 & $10,300,200.00$ & $8,248,600.00$ & $8,248,600.00$ \\
\hline 9 & Nov. 2017 & $11,869,200.00$ & $9,367,300.00$ & $9,367,300.00$ \\
\hline 10 & Dec. 2017 & $13,418,200.00$ & $10,370,100.00$ & $10,370,100.00$ \\
\hline 11 & Jan. 2018 & $15,078,565.00$ & $11,211,600.00$ & $11,211,600.00$ \\
\hline 12 & Feb. 2018 & $16,4,0,065.00$ & $12,321,600.00$ & $12,321,600.00$ \\
\hline 13 & Mar. 2018 & $17,002,557.00$ & $13,898,600.00$ & $13,898,600.00$ \\
\hline 14 & Apr.2018 & 0.00 & $15,772,449.00$ & $15,772,449.00$ \\
\hline 15 & May. 2018 & 0.00 & $16,326,659.00$ & $16,326,659.00$ \\
\hline 16 & Jun. 2018 & 0.00 & $17,002,557.00$ & $17,002,557.00$ \\
\hline
\end{tabular}


As a result of the value and cumulative processing of the data in the tables, exemplary charts of the EVM curves of the analysed values BCWS, ACWP, and BCWP in homogeneous groups, and also the BCWP chart in a diverse group, were determined.

\section{Research Results}

The results of studies concerning the course of cumulative cost curves in the EVM approach are presented for 6 out of 8 categories of groups, which are indicated in Table 1. Logistics Centres (Group E) and Health Centres (Group F) were excluded from the presentation of results due to the small number of measurements of ACWP and BCWP with regards to BCWS. The conclusions from the research of cost trends in the homogeneous groups $\mathrm{A}, \mathrm{B}, \mathrm{C}, \mathrm{D}, \mathrm{G}$ and $\mathrm{H}$, and conclusions from the studies of cost differences between these groups, are presented below.

\subsection{Results of Studies on the Cumulative Cost Curves in Homogeneous Groups According to the EVM}

3.1.1. The EVM in the group of Residential Buildings (A)

Figure 1 shows exemplary charts of the cumulative costs of an investment belonging to the group of Residential Buildings.

It is worth noting that an analysed construction investment was carried out in accordance with the planned budget. The ACWP curve coincides with the BCWP curve. In the first few months $(0.2<\mathrm{t}<0.6$, where $\mathrm{t}$ is the total duration of the project) of the analysed implementation, there is more progress than was planned (BCWP> ACWP).

The analysed residential buildings were built by a private construction developer, and they were financed from two sources: the contribution of the developer and a loan financed from the Bank.

The BCWP curves of the analysed investments, which are presented in Figure 2, graphically resemble line charts with a large angle of inclination in relation to the horizontal axis (abscissa). The large inclination indicates the steady and rapid progress of the analysed projects. For the analysed objects, the monthly increase in work progress is identical. It is also worth noting that the curves are almost parallel to each other. This results from a similar project management structure and a similar organization of the construction. For each of the three presented investments, the Investor and General Contractor were the same entities.

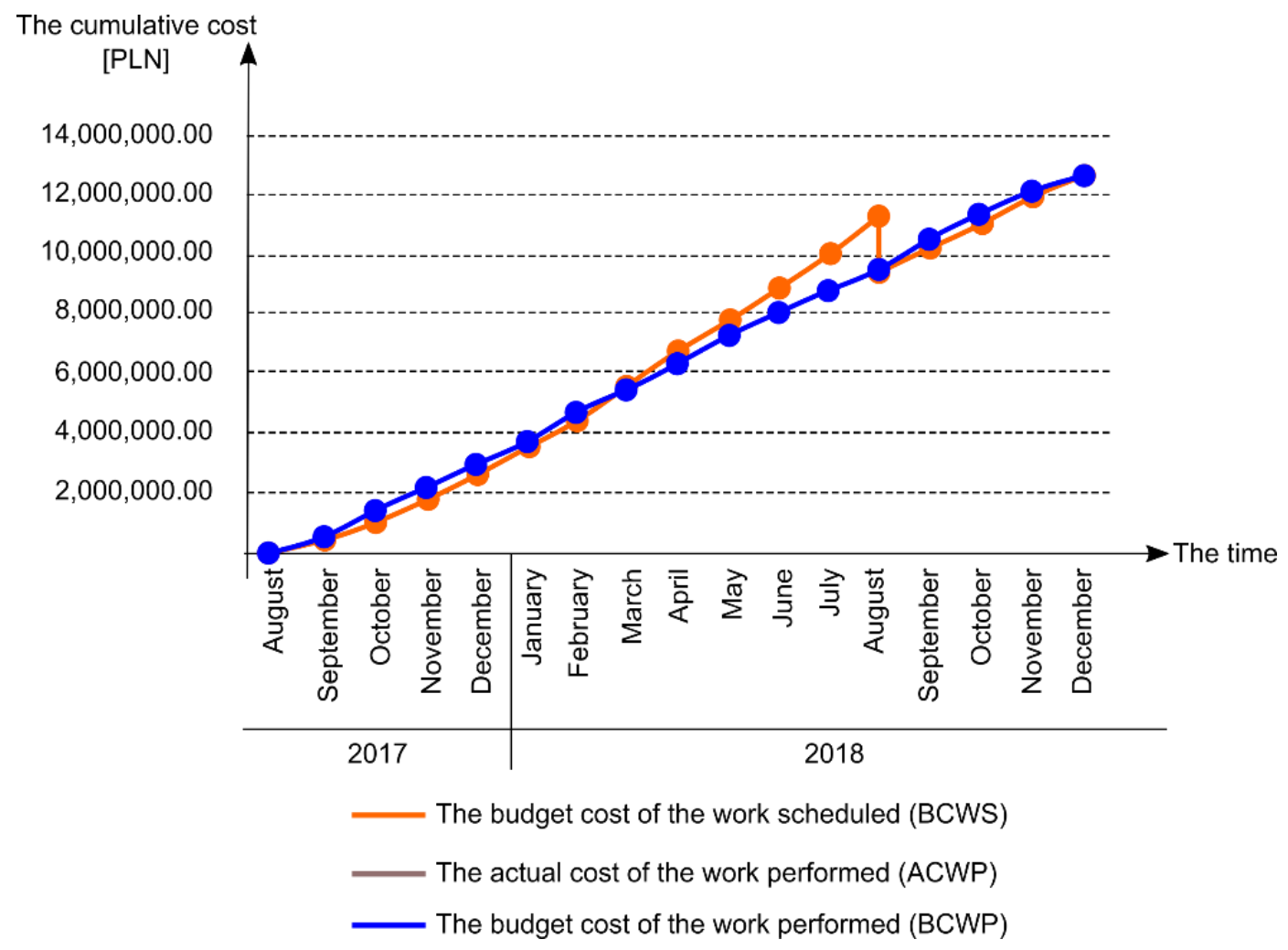

Figure 1. BCWS, ACWP and BCWP charts for an investment from the group of Residential Buildings 


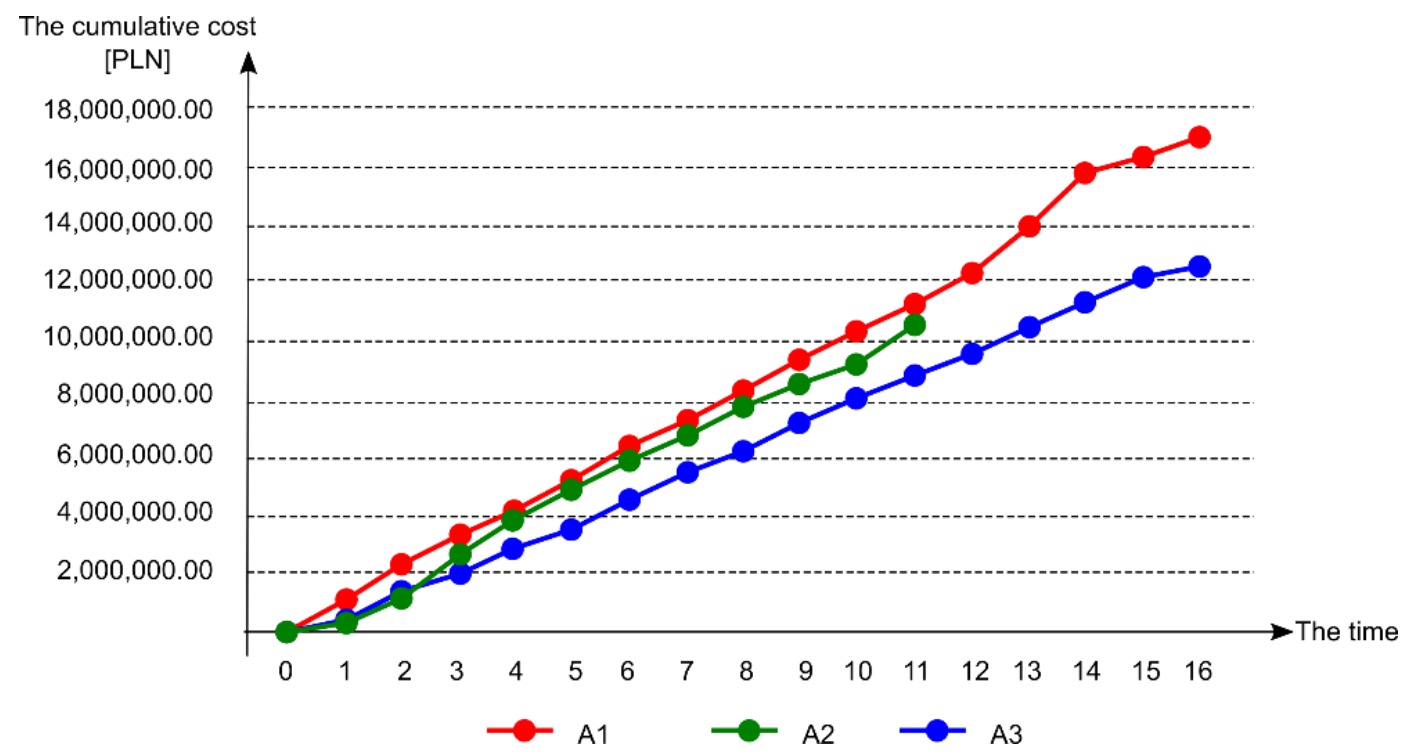

Figure 2. Comparison of the course of BCWP curves for 3 projects in the group of Residential Buildings

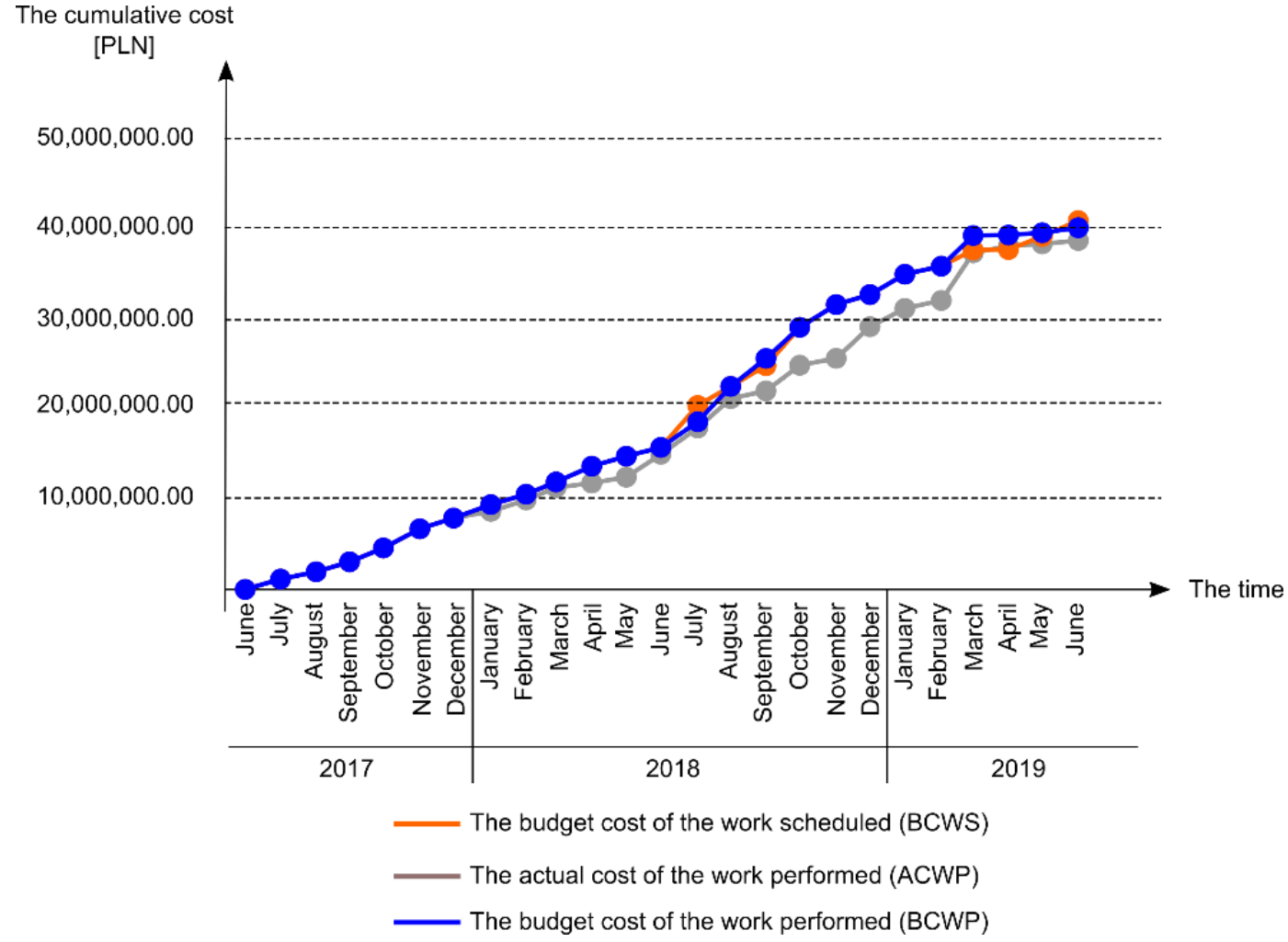

Figure 3. BCWS, ACWP and BCWP charts for an investment from the group of Office Buildings

\subsubsection{The EVM in the group of Office Buildings (B)}

Figure 3 shows exemplary charts of the cumulative costs of an investment belonging to the group of Office Buildings.

In the analysed project, the ACWP curve is located slightly below the BCWP curve, and the budget implementation ratios are bigger than one. This means that the works were carried out slightly cheaper than is assumed, and the final cost of the construction accounted for $99 \%$ of the assumed budget.
Figure 4 presents a collective chart of BCWP curves for 3 exemplary investments from the group of Office Buildings.

The obtained BCWP curves show the same trend, however, the shape of the letter "S" is disturbed. The inclination of the curves changes many times, which indicates an uneven work progress per unit of time. For a relatively long time after the start of the construction, only a small increase in costs is visible - the curves are flat. The implementation of works began to accelerate after exceeding the progress of the schedule by: $40 \%$ for 
project $\mathrm{B} 1,50 \%$ for project $\mathrm{B} 3$, and $60 \%$ for project $\mathrm{B} 2$, respectively.

\subsubsection{The EVM in the group of Hotel Buildings (C)}

Figure 5 shows exemplary charts of the cumulative costs of an investment belonging to the group of Hotel Buildings.

When analysing the charts presented in Figure 5, it can be seen that the BCWS curve, which is determined on the basis of the work and expenditure schedule, is discontinuous. There are numerous breaks resulting from the schedule being updated. Each annex to the contract required an update of the current schedule by the General Contractor. Moreover, the BCWP curve changes its inclination several times, which indicates frequent changes of the work progress per unit of time. Initially, the ACWP curve and the BCWP curve converge, however, after exceeding $65 \%$ of the work progress to be performed, the ACWP curve chart deviates (positive deviation from costs). This is a result of a partial suspension of payments for completed works, and also a deferred payment of invoices.

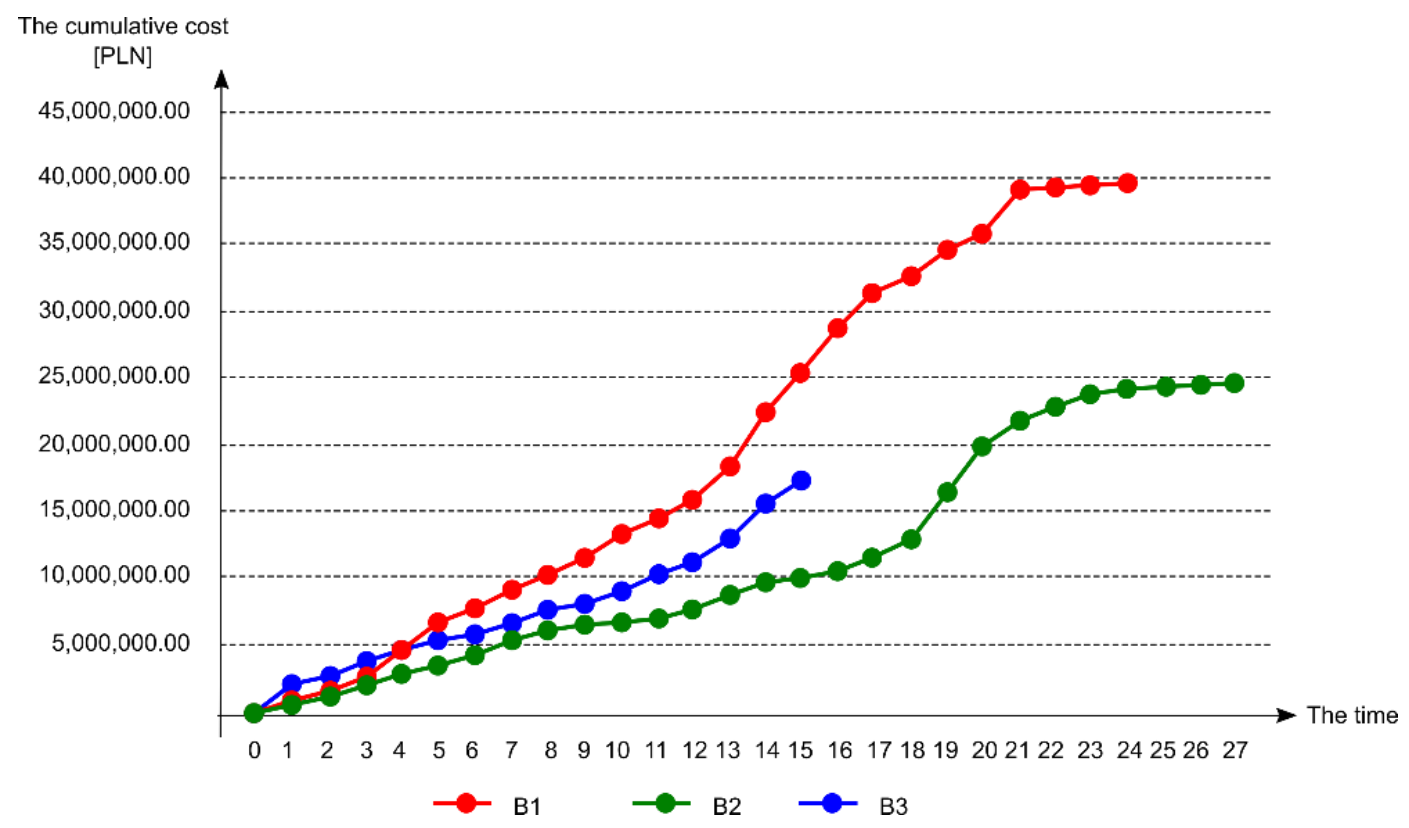

Figure 4. Comparison of the course of BCWP curves for 3 projects in the group of Office Buildings

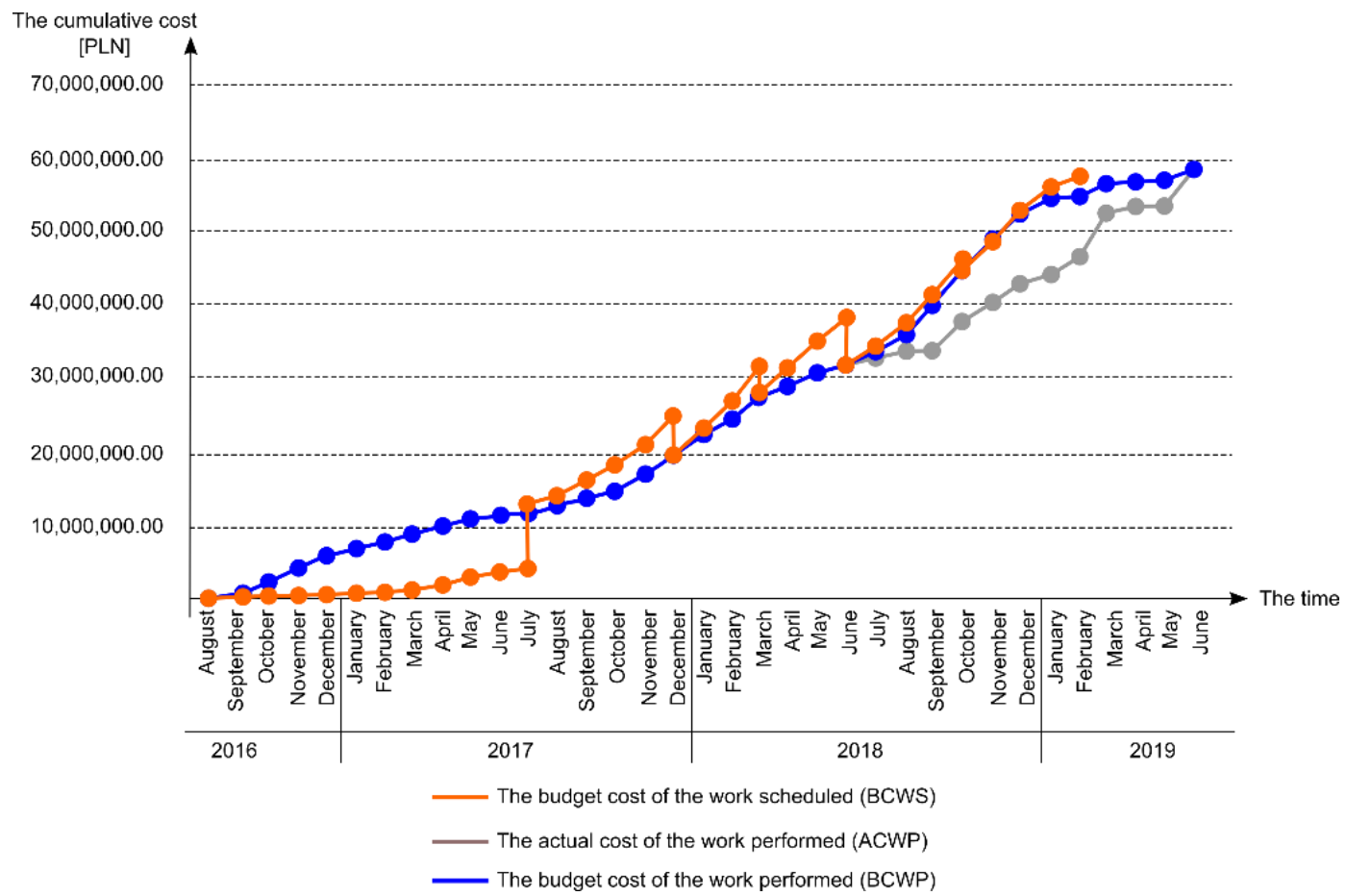

Figure 5. BCWS, ACWP and BCWP charts for an investment from the group of Hotel Buildings 
The cumulative cost

$[\mathrm{PLN}]$

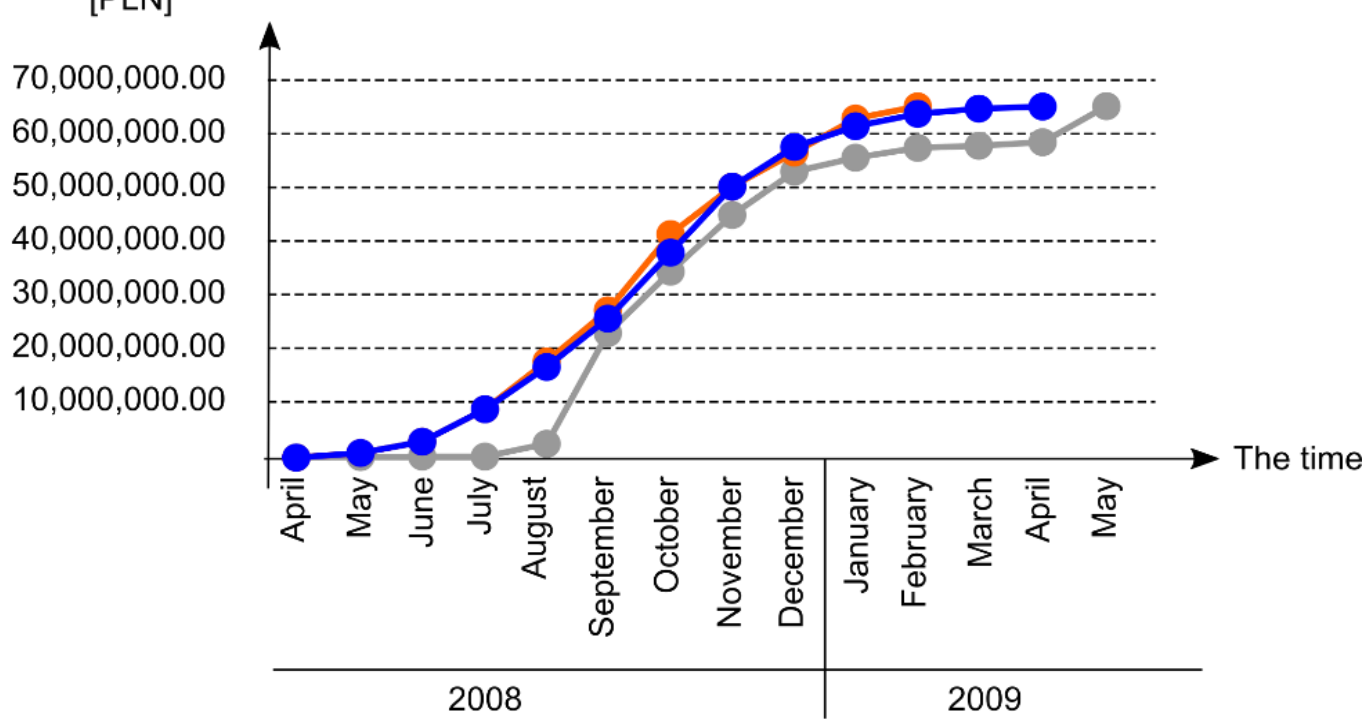

The budget cost of the work scheduled (BCWS)

The actual cost of the work performed (ACWP)

The budget cost of the work performed (BCWP)

Figure 6. BCWS, ACWP and BCWP charts for an investment from the group of Commercial and Leisure Centres

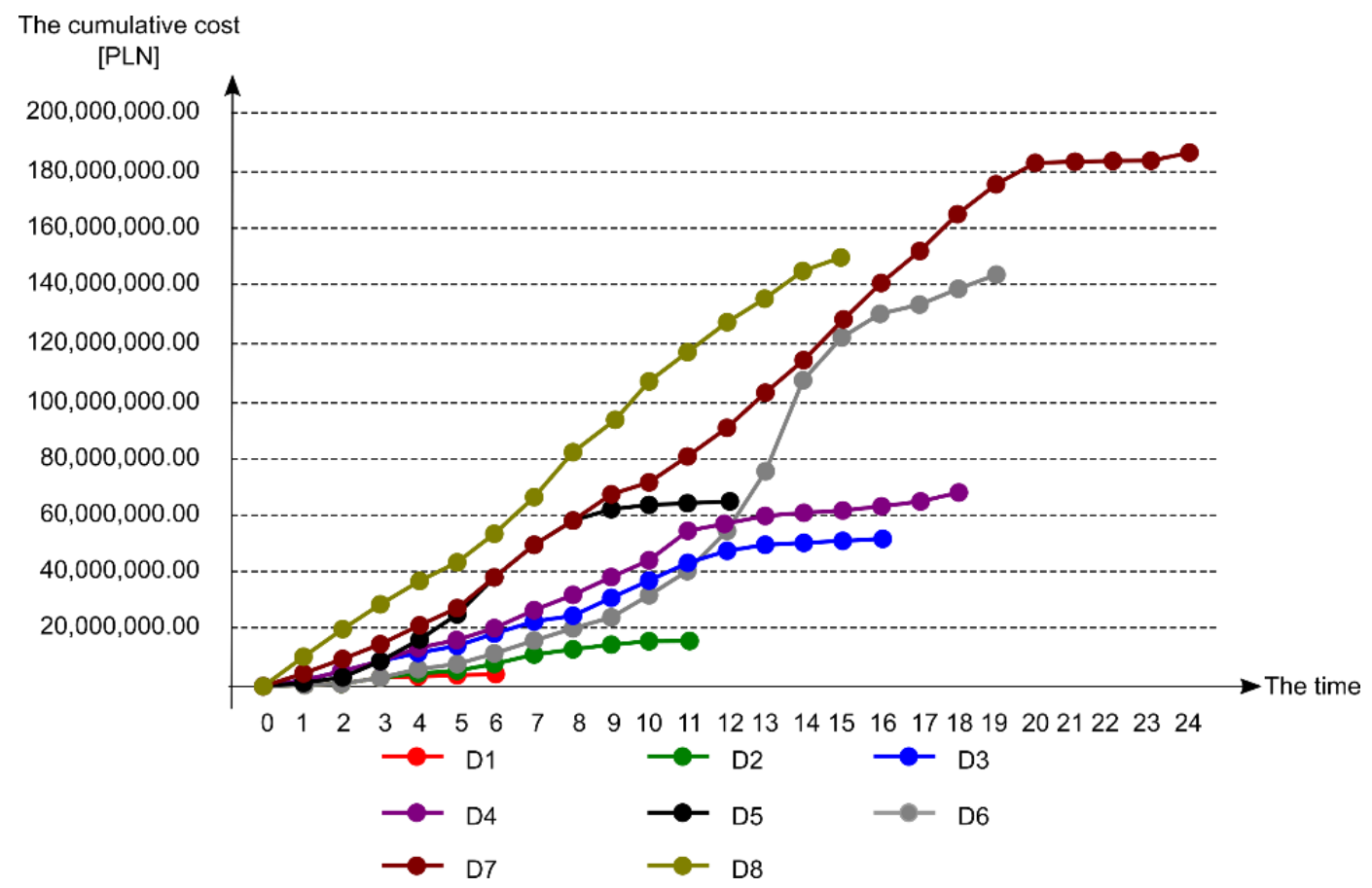

Figure 7. Comparison of the course of BCWP curves for 8 projects in the group of Commercial and Leisure Centres

3.1.4. The EVM in the group of Commercial and Leisure Centres (D)

Figure 6 shows exemplary charts of the cumulative costs of an investment belonging to the group of Commercial and Leisure Centres.

When analysing the chart in Figure 6, it can be seen that the values of the ACWP are significantly lower than the
BCWP for the entire duration of the works (positive CV index). It would seem that the works were performed cheaper than planned. However, this situation results from delays in payments to the General Contractor for works performed. It is noticeable that for the first 3 months of implementation, no payment was made, and ultimately the total cost of this construction project was the same as planned. 
Each analysed investment of the group of Commercial and Leisure Centres (D1 - D8) proceeded differently than planned. All projects recorded a negative deviation from the schedule at some stage of the work progress. For this reason, during the implementation of the two investments analysed in this point, it was decided to update the schedule. In the case of two construction projects, the BCWP curves negatively deviated from the BCWS (delay) from the first month of implementation. This was a consequence of a bad estimate of the work schedule. In addition, only 2 out of 8 analysed projects, which constitute $25 \%$, were completed within the assumed time frame. Other projects lasted longer than planned.

The course of the cumulative cost curves of the analysed Commercial and Leisure Centres is diverse. The BCWP charts, which correspond to D7 and D8, resemble linear functions. For these projects, a significant progress of works is noticeable from the beginning of the construction, and the curves take on a flatter shape in the final months of the implementation. Other projects are characterized by a visible division into 3 stages - a slow increase in the progress of works in the first and last phase of the construction, and the acceleration of implementation in the middle phase.

\subsubsection{The EVM in the group of Logistics Centres (E)}

Figure 8 shows exemplary charts of the cumulative costs of an investment belonging to the group of Logistics

\section{Centres.}

Figure 9 presents a collective chart of BCWP curves for 3 exemplary investments from the group of Logistics Centres.

The actual costs of works were higher by $1.3-2.1 \%$ when compared to the planned budget. In the case of the discussed G1 and G2 investments, works from the first month throughout the entire construction period were more expensive than expected, which indicates a poor estimate of the funds needed. In turn, for the five-month construction of the G3 investment (over $60 \%$ of the total duration of the construction), the financial outlay on construction works was lower than planned (positive deviation from the budget). However, these were not real savings, but only reduced payments. This was compensated in the last month of the works.

The cumulative cost charts, which are presented in Figure 9, do not resemble the letter "S" during their whole course - the curves at the beginning and end of the implementation are flatter, and the inclination between them is steep. The progress of each implementation for the first 3 months was greater than planned. Afterwards, there was a negative deviation from the schedule $(\mathrm{SV}<0)$, which indicates a delay in works. Both the investment G1 and $\mathrm{G} 2$ recorded the same extension of implementation time by 2 months. The described projects lasted over $30 \%$ longer than was assumed in the original schedule.

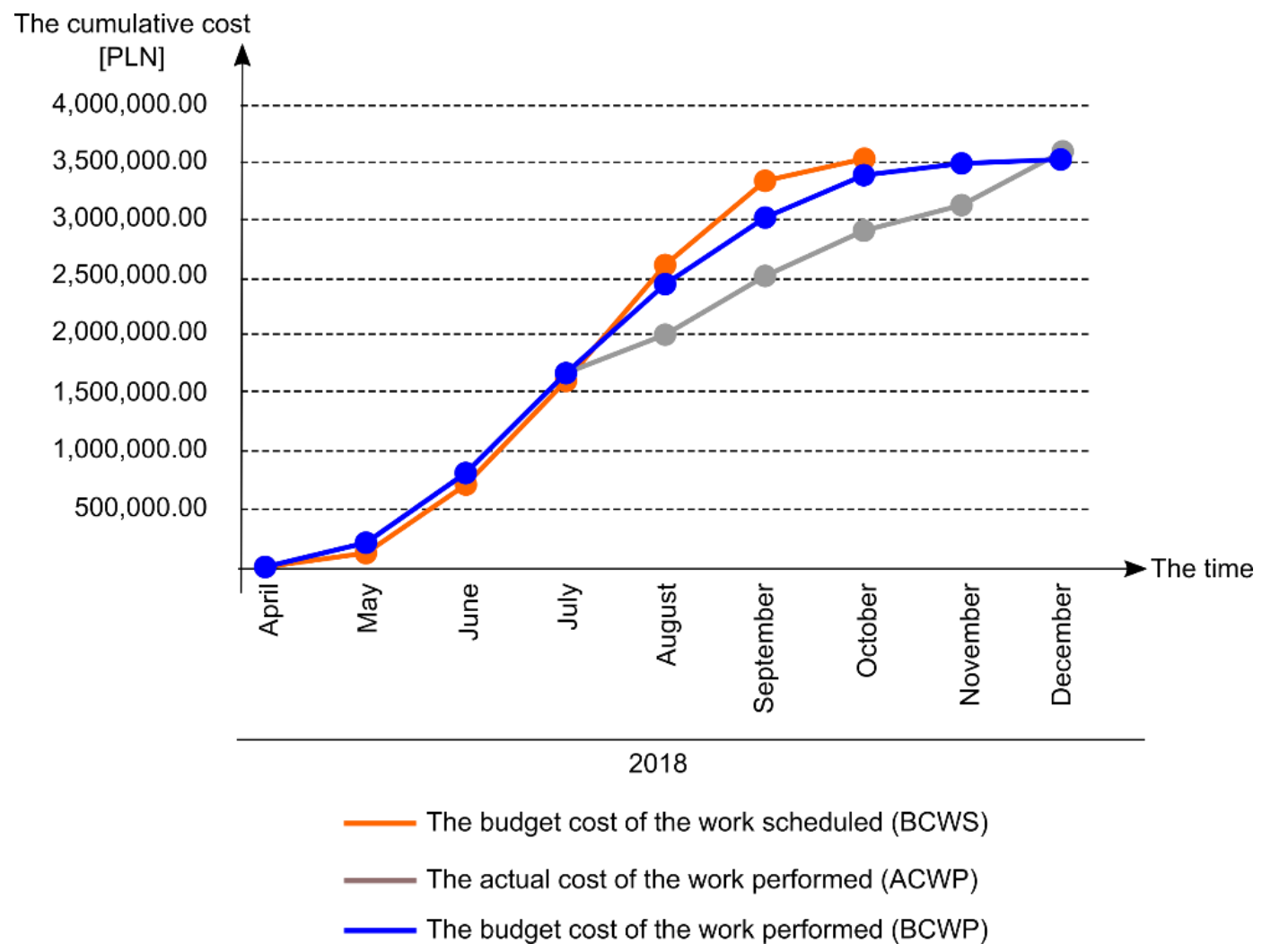

Figure 8. BCWS, ACWP and BCWP charts for an investment from the group of Logistics Centres 


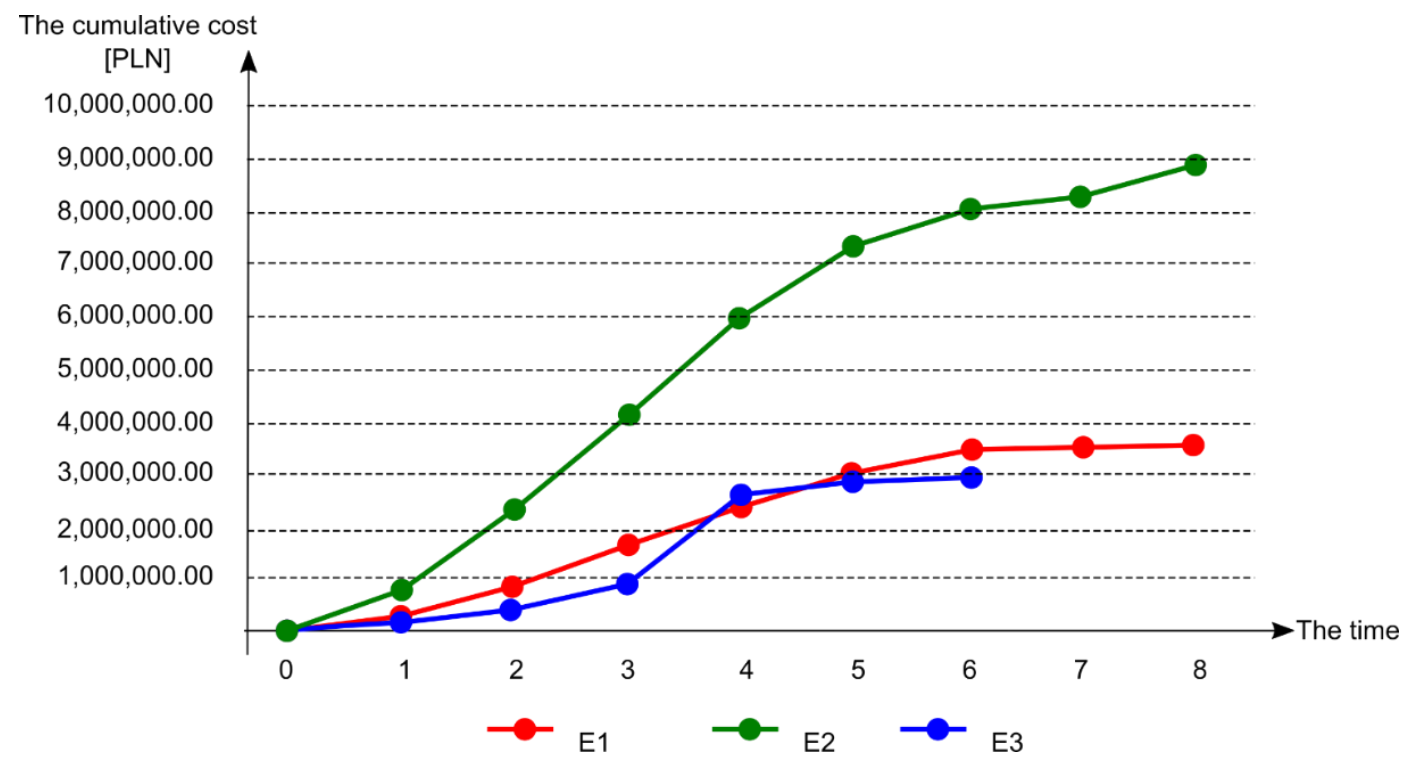

Figure 9. Comparison of the course of BCWP curves for 3 projects in the group of Commercial and Leisure Centres

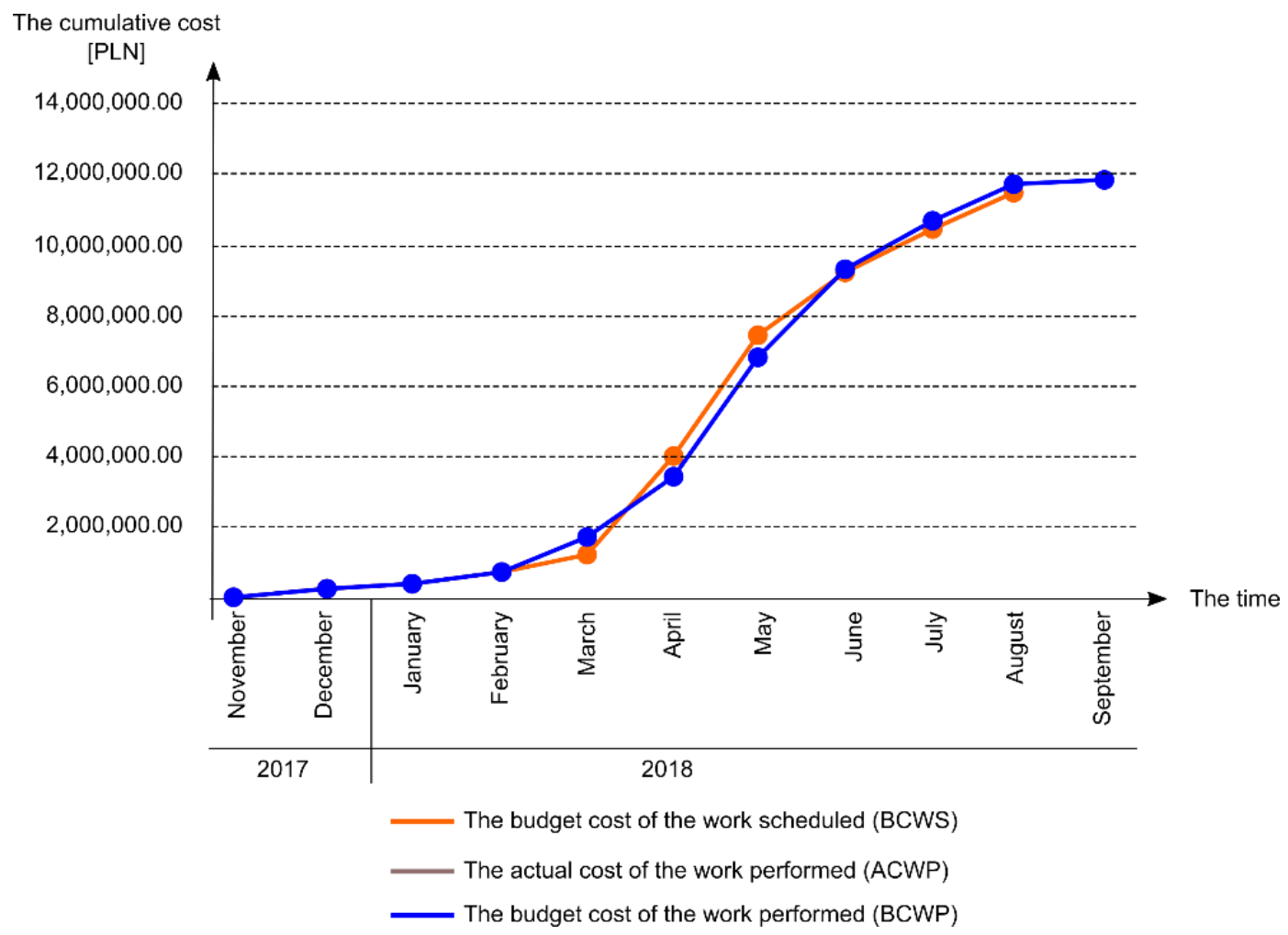

Figure 10. BCWS, ACWP and BCWP charts for an investment from the group of Production Plants

\subsubsection{The EVM for the Production Plants $(\mathrm{H})$}

Figure 10 shows exemplary charts of the cumulative costs of an investment belonging to the group of Production Plants.

In Figure 10, the ACWP and BCWP curves coincide, which means that the cost of the work performed was the same as planned. Ultimately, the implementation was completed 1 month after the deadline, and exceeded the planned budget by $2 \%$. This was caused by the need for the General Contractor to perform additional works that were not included in the cost estimate and schedule. During the first half of the investment duration, progress was low. A small inclination angle of the BCWP curve with regards to the abscissa is visible. In the second half of the duration, the works accelerated significantly - the chart is steep.

\subsection{Results of Studies on the Cumulative Cost Curves in Different Construction Sectors}

When analysing the shapes of the curves within the 
sector of a homogeneous investment group, it can be concluded that they are similar. However, when comparing different groups of investment tasks, a big difference is visible. The determined curves for Residential Buildings (A) are characterized by the pursuit of linearity. The BCWP charts of Office Buildings (B) repeatedly change and their inclination in relation to the abscissa is small. In contrast to the curves of the Logistics Centres (E), which are steeper from the beginning, they maintain the literary shape of the letter $\mathrm{S}$.

Due to the large diversity of Commercial and Leisure Centres (D), the curves of this group are characterized by great diversity. There are charts with a small initial increment, charts that are inclined at a large angle, charts that resemble straight lines, as well as charts with significant curvatures.

Moreover, for each investment task that belongs to Residential Buildings (A), works were carried out faster than expected (positive deviation from the schedule) in the first months of the construction, whereas all Office Buildings (B) were implemented according to plan (schedule deviation equal to zero) in the initial phase. In turn, investments related to Commercial and Leisure Centres (D) recorded both positive and negative deviations from the schedule, as well as no deviations at all - the works were carried out as planned in the first month of construction.

In addition, the actual cost of works performed in individual months of construction of each analysed Residential Building (A) was as planned, i.e., ACWP = BCWP. However, in the case of all Office Buildings (B), $75 \%$ of the examined Commercial and Leisure Centres (D), the actual cost of works was lower than planned over almost the entire duration of the project (ACWP <BCWP) due to the use of the deferred payment system.

\section{Discussion and Summary}

An appropriate cost planning has a significant impact on both the overall liquidity of construction companies and the achievement of success in the implementation of construction projects. The obtaining of a rational estimate of the S-curve, which reflects reality, before the start of the construction project is important for all participants that are involved in the implementation of the investment project, in particular for the investor and contractors. The S-curve is a helpful tool for the planning, monitoring and control of construction projects [2,13,34,35].

The S-curve is the basis for forecasting cash flows. Unfortunately, it is very unlikely that the project will go according to plan in every respect. Small deviations between the plan and reality can be seen as being within the norm and usually do not interfere with achieving the goal. However, larger differences can hinder the achievement of the goal, and therefore they require changes in the plan for the future. They also require revision in order to ensure the achievement of the main objectives of the project.

The Earned Value Method is a simple tool that enables schedule performance and the use of the budget to be monitored. When using several indicators, which are based on information about the scope, date and cost, the progress of the project can be analysed; scales, causes and consequences of deviations can be interpreted; and the further course of the implementation, including predispositions to complete the project within the assumed budget and deadline, can be assessed. Due to this, the Earned Value Method is widely known and used to control projects around the world [12,14-17,22,29,32,37-40].

The main problem of traditional cost management systems in the investment process used by construction companies and management companies is the late delivery of information concerning cost and budget overruns. In order to minimize these problems, various cost control and monitoring techniques are used, i.e., the analysis of S-curves, or the Earned Value Method.

The analysis of S-curves is commonly used for project planning and cost control, but the traditional method of estimating S-curves, which is based only on the work and expenditure schedule, is not always accurate. The conducted analysis of several dozen S-curves, which was carried out in the article, shows that the previously proposed models of forecasting S-curves usually deviate from reality, and are too complicated. Therefore, they are not practical for the planning and management of construction projects, because the uniqueness of cumulative cost curves of each project are different.

Therefore, an alternative solution is to use the Earned Value Method in analyses. The Earned Value method is affordable and provides a relatively accurate assessment of the problem. The analyses carried out in the article indicate that both the estimated cost and duration are very sensitive to the data that was used in the analyses. In order to obtain the most reliable and real estimate of the costs and duration of an investment, analyses should be conducted in accordance with the actual progress of the project. This was done by the authors of the article in several hundred technical and financial inspections at construction sites throughout Poland [2,31]. The estimated actual costs and duration are not reliable in the first period of the project, and they only stabilize with greater accuracy in the second period of the investment process.

By a deep review of the other researchers, it is found that the proposed models of determining $\mathrm{S}$-curves differ from reality and seem to be too complex. Therefore, they are not useful for planning and management of construction projects $[3,8,13-16]$, because the cumulative cost curves vary a lot from one another. Each construction project has its own nature - technical, financial and geographical parameters. In addition, it is formatted and 
managed by individuals of different professional qualifications and experience. Construction works are executed by various organizational and technological approaches. Each construction project is therefore a separate challenge with its own randomness, uncertainties and risks.

Many published papers and results of research concerning the costs of various investment tasks are limited to the analysis of selected cases [15,33], and are not supported with reliable measurements of earned costs. Other works have a methodological character and profile, and indicate the tools and parameters for measuring costs in the Earned Value Method [1,2,11,18,28,30]. In turn, other publications present an interesting approach to the issue of incurred and additional costs in the category of fuzzy sets [21-23], and also quantify the cost of unforeseen works as a function of belonging to a set, which is referred to as an investment budget.

It is difficult to find publications with an accepted research methodology, in which the planned, incurred, and performed values of the costs of diversified investment tasks, the deviations of these costs, and their causes, are presented. Such data was collected and processed by the authors of the article by conducting monthly direct technical and financial inspections at construction sites of implemented investments. The collected data was the result of measurements of the current state of the amount of work performed / measurements of the execution of construction works. Increasing values of the amount of work performed on the construction sites constituted the cumulative cost. This cost, which was designated periodically and consistently by the same authors using the audit approach to measurements, determined the course of the S-curve that corresponds to the monitored and controlled construction investment [2,31,43-45]. Collected, measured and processed data concerning the completed construction investments must be considered reliable, consistent and legible.

They can be used to extract typological research samples for investments of a similar profile, or investments divided into the categories of the construction objects presented above [46]. Measurements of the cost of construction works with a number exceeding 100 documented in Bank Supervision reports - can be additionally extrapolated to homogeneous populations, which correspond, e.g., with construction sectors in Poland.

The conducted research works, which are briefly presented in this article, relate to various construction projects. Calculations made in accordance with Earned Value Method enabled the assessment of the actual costs and the individual investment tasks to be conducted. According to the obtained results, analogies were observed in the shaping of the trend of cumulative cash flow curves, both within the same groups of buildings, and also between them.

\section{REFERENCES}

[1] M. Gunduz, M. Almuajebh. Critical Success Factors for Sustainable Construction Project Management. Sustainability 2020, 12, 1990.

[2] J. Konior, M. Szóstak, The S-Curve as a Tool for Planning and Controlling of Construction Process-Case Study. Appl. Sci. 2020, Vol. 10, Page 2071 2020, 10, 2071.

[3] H. Wang, Y. Hu. Research on the System of the Construction Project Life Cycle Cost Risk Management. Appl. Mech. Mater. 2011, 94-96, 2329-2332.

[4] E. Zavadskas, Z. Turskis, J. Tamošaitienè. Risk assessment of construction projects. J. Civ. Eng. Manag. 2010, 16, 3346.

[5] T. Kasprowicz. Quantitative Assessment of Construction Risk. Arch. Civ. Eng. 2017, 63, 55-66.

[6] T. Kasprowicz. Quantitative Identification of Construction Risk. Arch. Civ. Eng. 2017, 63, 63-75.

[7] S. Vandevoorde, M. Vanhoucke. A comparison of different project duration forecasting methods using earned value metrics. Int. J. Proj. Manag. 2006, 24, 289-302.

[8] A. M. Kamaruddeen; C. F. Sung, W. Wahi, "A Study on Factors Causing Cost Overrun of Construction Projects in Sarawak, Malaysia," Civil Engineering and Architecture, Vol 8, No 3, PP. $191-199$, 2020. DOI: 10.13189/cea.2020.080301.

[9] S. Al-Jibouri. Monitoring systems and their effectiveness for project cost control in construction. Int. J. Proj. Manag. 2003, $21,145-154$.

[10] Project Management Institute, P. A guide to the project management body of knowledge (PMBOK guide) 6th Edition; Project Management Institute (PMI), 2017; ISBN 9781935589679.

[11] A. Czarnigowska. Earned value method as a tool for project control. Bud. i Archit. 2008, 3, 15-32.

[12] H. Chen, W. Chen, Y. Lin. Earned value project management: Improving the predictive power of planned value. Int. J. Proj. Manag. 2016, 34, 22-29.

[13] L. Chao, H. Chen. Predicting project progress via estimation of S-curve's key geometric feature values. Autom. Constr. 2015, 57, 33-41.

[14] A. De Marco, T. Narbaev. Earned value-based performance monitoring of facility construction projects. J. Facil. Manag. 2013, 11, 69-80.

[15] M. Waris, M. Khamidi; A. Idrus. The Cost Monitoring of Construction Projects through Earned Value Analysis. J. Constr. Eng. Proj. Manag. 2012, 2, 42-45.

[16] T. Chin-Keng, N. Shahdan. The Application of Earned Value Management (EVM) in Construction Project Management. J. Technol. Manag. Bus. 2015, 2.

[17] A. Ziółkowska, M. Połoński. Application of the EVM method and its extensions in the implementation of 
construction objects. Eng. Struct. Technol. 2015, 7, 189-196.

[18] M. Połoński. Management of construction investment process; Wydawnictwo SGGW (in Polish), 2018; ISBN 9788375830873.

[19] H. Kerzner. Project Management: A Systems Approach to Planning, Scheduling, and Controlling,; John Wiley\&Sons, Inc.: New York, USA, 2003;

[20] J. Chou. Cost simulation in an item-based project involving construction engineering and management. Int. J. Proj. Manag. 2011, 29, 706-717.

[21] A. Leśniak, D. Kubek, E. Plebankiewicz; K. Zima, K. Belniak. Fuzzy AHP Application for Supporting Contractors' Bidding Decision. Symmetry (Basel). 2018, 10, 642.

[22] K. Lam, A. So, T. Hu, T. Ng, R. Yuen, S. Lo, S. Cheung, H. Yang. An integration of the fuzzy reasoning technique and the fuzzy optimization method in construction project management decision-making. Constr. Manag. Econ. 2001, $19,63-76$.

[23] M. Cheng, A. Roy. Evolutionary fuzzy decision model for cash flow prediction using time-dependent support vector machines. Int. J. Proj. Manag. 2011, 29, 56-65.

[24]E. Plebankiewicz, K. Zima,D. Wieczorek. Quantification of the risk addition in life cycle cost of a building object. Tech. Trans. 2017, 5, 35-45.

[25] IPMA IPMA Individual Competence Baseline; 2015;

[26] Pungky Dharma Saputra, Yusuf Latief, "Development of Safety Plan Based on Work Breakdown Structure to Determine Safety Cost for Precast Concrete Bridge Construction Projects. Case Study: Girder Erection with Launching Gantry Method," Civil Engineering and Architecture, Vol. 8, No. 3, pp. 297-304, 2020, DOI: 10.13189/cea.2020.080313

[27] D. Wieczorek. Monitoring of Projects Costs Using Earned Value. Pap. Reports Fac. Manag. Gdansk Univ. (in Polish) 2006, 1, 551-560.

[28] M. Połoński, M. Kontrola kosztów realizacji obiektu budowlanego metodą Earned Value. In Inżynieria przedsięwzięć budowlanych: Rekomendowane metody i techniki; 2015.

[29] H. Anysz,J. Zawistowski. Cost-time control of the progress of construction works using the earned value method using MS Project (in Polish: Kontrola kosztowo-czasowa postępu robót budowlanych metodą wartości wypracowanej $\mathrm{z}$ wykorzystaniem programu MS Project). In Principles and standards of cost estimation of construction works for awarding entities, investors and contractors (in Polish: Zasady i standardy kosztorysowania robót budowlanych dla zamawiających, inwestorów i wykonawców); 2017; pp. 7188 .

[30] M. Połoński, P. Komendarek. Earned value method for operational cost control of civil structure. Metod. ilościowe w badaniach Ekon. 2011, 12, 279-290.

[31] J. Konior, M. Szóstak. Methodology of Planning the Course of the Cumulative Cost Curve in Construction Projects. Sustain. 2020, Vol. 12, Page 2347 2020, 12, 2347.

[32] W. Abba. How earned value got to primetime: a short look back and glance ahead. In Proceedings of the Project Management Institute Annual Seminars \& Symposium; Project Management Institute (PMI): Houston, TX. Newtown Square, 2000.

[33] M. Klinowski. Analysis of the current and forecast of the future realization of the project on the basis of earned value method. Res. Pap. Wrocław Univ. Econ. (in Polish) 2014, $335,105-115$.

[34] J. Cristóbal. The S-curve envelope as a tool for monitoring and control of projects. Procedia Comput. Sci. 2017, 121, 756-761.

[35] K. Tijanić, D. Car-Pušić. Application of S-curve in EVA Method. In Proceedings of the 13th International Conference "Organization, Technology and Management in Construction"; 2017; pp. 103-115.

[36] E. Kozień. Application of approximation technique to on-line updating of the actual cost curve in the earned value method. Czas. Tech. 2017, 9, 181-195.

[37] A. Czemplik. Application of earned value method to progress control of construction projects. Procedia Eng. 2014, 91, $424-428$

[38] D. Przywara, A. Rak. The time-cost analysis of schedule monitoring using the earned value method. Tech. Trans. 2017, $5,57-66$.

[39] A. Dziadosz, O. Kapliński, M. Rejment. Usefulness and fields of the application of the Earned Value Management in the implementation of construction projects. Bud. i Archit. 2014, 13, 357-364.

[40] A. Czarnigowska. Monitoring of project progress using the Earned Value. Przegląd Bud. (in Polish) 2009, 80, 50-55.

[41]R. Howes. Improving the performance of Earned Value Analysis as a construction project management tool. Eng. Constr. Archit. Manag. 2000, 7, 399-411.

[42]Z. Yaseen, Z. Ali, W. Salih, N. Al-Ansari. Prediction of Risk Delay in Construction Projects Using a Hybrid Artificial Intelligence Model. Sustainability 2020, 12, 1514.

[43] J. Konior. Significance Risks Evaluation of Commercial Construction Projects. Arch. Civ. Eng. 2019, 65, 19-33.

[44] J. Konior. Feasibility Study of Construction Project in Compliance with Bank Investment Supervision Requirements. J. Civ. Eng. Archit. 2018, 12, 831-837.

[45] Jarosław Konior, "Monitoring of Construction Projects Feasibility by Bank Investment Supervision Approach," Civil Engineering and Architecture, Vol. 7, No. 1, pp. 31-35, 2019, DOI: 10.13189/cea.2019.070105

[46] A. Bauer-Celny; J. Konior; M. Szóstak. Initial, Monthly, Close-out Reporting of Bank Investment Supervision. PM Group Polska sp. z o.o. 2006 - 2015, 3EPCM sp. z o.o. 2016 $-2019$ 